\title{
Endoscopic Selective Neck Dissection via Retroauricular Approach
}

\author{
Joo Hyun Kim ${ }^{1}$ and Jae Hong Park ${ }^{2}$ (D) \\ ${ }^{1}$ Department of Otorhinolaryngology-Head and Neck Surgery, Yongin Severance Hospital, Yonsei University College of Medicine, \\ Yongin; and \\ ${ }^{2}$ Department of Otolaryngology-Head and Neck Surgery, Soonchunhyang University College of Medicine, Cheonan, Korea
}

\section{후이개 접근법을 이용한 내시경 선택적 경부절제술}

김주현 ${ }^{1} \cdot$ 박재홍 $^{2}$

연세대학교 의과대학 용인세브란스병원 이비인후과학교실, ${ }^{1}$ 순천향대학교 의과대학 천안병원 이비인후과학교실 ${ }^{2}$

\author{
Received February 13, 2021 \\ Revised March 11, 2021 \\ Accepted March 15, 2021 \\ Address for correspondence \\ Jae Hong Park, MD, PhD \\ Department of Otolaryngology- \\ Head and Neck Surgery, \\ Soonchunhyang University \\ College of Medicine, \\ 31 Soonchunhyang 6-gil, \\ Dongnam-gu, Cheonan 31151, Korea \\ Tel +82-82-41-570-2765 \\ Fax $+82-41-592-3803$ \\ E-mail entparkong@hanmail.net
}

Lymph node metastasis is the single, most powerful prognostic factor in head and neck squamous cell cancer, which means that cervical lymph node management should be considered even in treatment of a clinically node-negative neck. More conservative and selective techniques of neck dissection have been developed ever since radical neck dissection was first introduced. Despite that selective neck dissection provides less functional damage, disfiguring scar after neck dissection still remains inevitable. Recently, surgical endoscopy and robotic system was introduced and many clinical trials for aesthetic approach for neck dissection using endoscopy have shown their feasibility and safety. Hereby, we describe the preparation and surgical procedure for endoscopic selective neck dissection (level I, II, and III) via retroauricular approach for 41-year-old male patient with clinically node-negative oral tongue cancer. Korean J Otorhinolaryngol-Head Neck Surg 2021;64(4):285-9

Key Words Endoscopy - Lymph node - Neck dissection.

\section{서 론}

림프절 전이는 두경부암의 예후를 결정짓는 가장 중요한 인자이기에 비록 임상적으로 림프절 전이소견이 없는 두경부 암이라 할지라도 경부 림프절 치료는 신중히 고려되어 왔다. ${ }^{1,2}$ 1963년 Suárez Suárez)에 의해 처음 소개된 변형 근치적 경 부절제술(modified radical neck dissection)은 기능보존적 경부절제술(functional neck dissection)의 모태가 되었고, 1985년 Byers)에 의해 도입된 선택적 경부절제술(selective neck dissection)은 기존의 근치적 경부절제술(radical neck dissection)에 비해, 보다 선택적이며 기능손상이 덜한 제한

This is an Open Access article distributed under the terms of the Creative Commons Attribution Non-Commercial License (https://creativecommons.org/licenses/by-nc/4.0) which permits unrestricted non-commercial use, distribution, and reproduction in any medium, provided the original work is properly cited.
된 구역의 경부절제술을 가능하게 하였다. 좀 더 선택적이고 제한된 구역을 선별적으로 치료하여 경부기능을 보존하고자 하는 노력에 비해, 경부절제술 후 반흔은 접근법의 변화 없이 는 피할 수 없는 숙제로 남게 되었다.

최근, 내시경과 수술용 로봇의 도입에 따라 일부 수술에 있어서 흉터를 최소화하거나 보이지 않는 곳에 남길 수 있는 접근법들이 개발되었고, 두경부수술에 있어서도 다양한 접근 법을 통한 내시경 수술이 가능해져, 그 효율성과 안전성에 대 하여는 이미 다양한 문헌을 통해 보고된 바 있다. ${ }^{5-8)}$ 이에 저 자는 후이개 접근법을 통한 내시경 수술을 이용하여 반흔을 최소화할 수 있는 선택적 경부절제술의 준비와 수술 과정을 저자의 경험과 함께 소개하고자 한다. 


\section{방 법}

\section{수술 전 평가(Preoperative assessment)}

수술 전 영상의학적 평가과정은 선택적 경부절제술을 요 하는 일반적인 경우와 다르지 않다. CT, MRI와 PET-CT를 통해 경부 림프절전이 여부와 위치를 확인하며 적응증 또한 일반적인 예방적 선택적 경부절제술의 경우와 동일하다. 다만, 치료 목적의 선택적 경부절제술을 시행하는 소수의 제한된 경우에 있어서는, 후이개 접근법을 통하여 종괴가 충분히 노 출이 가능한지, 수술 전 충분한 검토를 필요로 하며 주변조직 과의 유착 또는 피막 외 침범이 영상검사상 확인이 되거나 전 이성 병변의 크기가 크고 노출이 제한되는 경우에는 상대적 인 금기증이라 할 수 있겠다. 단, 경부구역 Ib, II, III 상부에 위치한 병변의 경우에는 후이개 접근법을 통한다 하더라도 직접적인 시야하에서 수술이 가능하며, 술자의 손이 직접 닿 는 거리에 병변이 위치한 경우가 많아 일반적인 림프절 청소 술과 그 술식에 있어 크게 다르지 않으므로, 적응증에 있어 서도 병변의 위치와 절제범위가 무엇보다 중요하다고 할 수 있겠다. 기타 흥쇄유돌근이 과도하게 비대한 경우, 목이 두껍 고 짧아서 경부 신전과 회전이 제한되는 경우에 있어서도 절 제할 범위와 노출 정도를 고려하여 수술 가능 여부를 결정해 야 한다.

\section{수술 기구(Surgical instruments)(Fig. 1)}

- Skin hook

- Army-Navy retractor

- Right-angle retractor
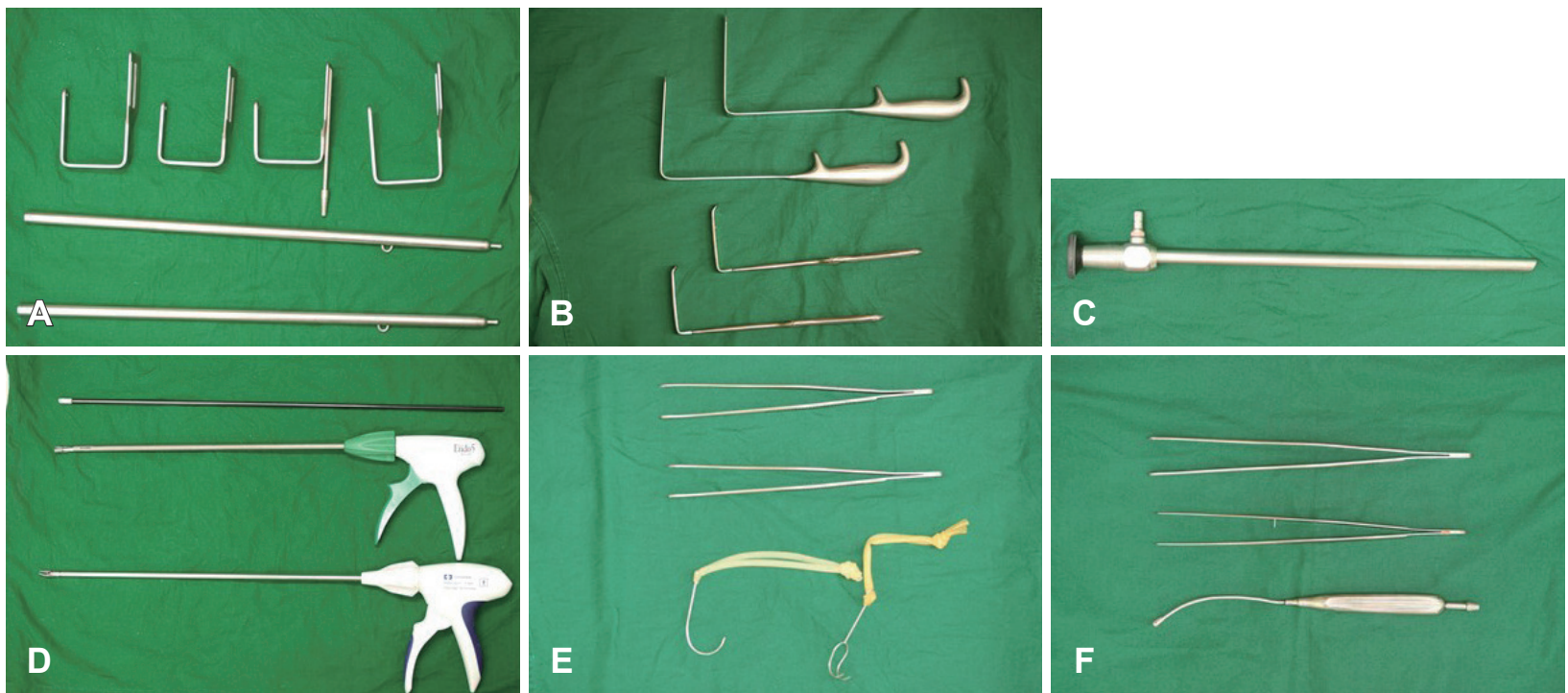

Fig. 1. Surgical instruments. Self-retaining retractors (L \& C Bio) (A). Right-angle retractors (B). $12 \mathrm{~mm} 25-\mathrm{deg} r e e$ face-down dual endoscope (C). Endoscopic dissectors (5 mm Endo dissect ${ }^{\mathrm{TM}}$, Coviden) and ligating clip applier (Wec ${ }^{\circledR}$ Hem-o-lok $^{\circledR}$ Auto Endo5 ${ }^{\circledR}$, Teleflex ${ }^{\circledR}$ ) (D). Debakey forceps and skin hooks (E). Russian forceps and Yankauer suction (F). 


\section{절개선 고안}

동측 후이개 모발선으로부터 내측 $5 \mathrm{~mm}$ 후방에 모발선과 평행한 선을 고안 후 이개 후면의 주름과 상부에서 완만한 곡 선으로 부드럽게 연결되는 절개선을 고안한다.

\section{피판 거상}

피판 거상 시에 대이개신경(great auricular nerve)과 외경 정맥(external jugular vein)을 확인하여 보존하여야 하며, 이는 흥쇄유돌근막 및 이하선(parotid gland) 피막에 손상을 주지 않기 위한 좋은 해부학적 표지물(landmark)일 뿐만 아 니라 외경정맥 주변에서 광경근(platysma muscle)의 바깥 경 계를 쉽게 발견할 수 있어 중요한 임상적 의미가 있는 구조물 이라 할 수 있겠다. 광경근의 경계를 확인 후 광경근하 공간 으로 박리를 진행하되, 1 구역에서는 특히 광경근에 바짝 붙여 박리하여 안면신경 하악분지(marginal mandibular branch of facial nerve)의 손상이 없도록 주의한다. 위로는 하악(mandible) 하연, 내측으로는 반대측 이복근 전복(anterior belly of digastric muscle)과 혁대근(strap muscle)의 바깥 경계가 충분히 확인될 때까지 박리하며, 아래로는 흥골절흔(sternal notch)과 쇄골(clavicle) 상부가 석션기를 통해 촉지될 때까지 충분히 박리하여 수술 공간의 넓이뿐만 아니라 높이까지 충 분히 확보되도록 한다. 이는 내시경과 기구들의 간섭을 최소 화하기 위해서도 중요하지만 높이가 충분하지 않은 공간을 무리하게 견인기로 거상 시 앞뒤 공간이 가운데로 모이게 되 어 좁아지는 효과가 있으며, 박리되지 않은 조직이 내측으로 당겨지게 되어 림프절 청소술 시 공간을 더욱 비좁게 할 여지 가 있다.

\section{내시경 도입 전 수술 시야 박리}

피판을 거상 후 자가견인기를 통해 박리하고자 하는 구역 을 따라 견인기를 고정 후 후크(skin hook)를 이용하여 양측 피판을 견인한다(Fig. 2). 이후 보조자로 하여금 직각견인기 (right-angle retractor)로 자가견인기에 의해 견인된 부위 하 방의 피판을 추가로 견인하도록 한다(Fig. 2). 이상의 과정을 통해 이상적인 공간이 확보되었다면 술자의 손이 자유롭게 공간 내로 진입이 가능할 뿐만 아니라 수술 공간이 모두 시 야 안에 들어올 수 있게 된다. 이후의 수술 과정은 내시경을 수술 공간에 도입하기 전 과정과 내시경 도입 후 내시경 시야 에서의 박리 과정으로 나뉘게 되나, 일반적인 경부절제술의 술식과 크게 다르지 않아 시야를 효율적으로 확보하기 위해 내시경을 거치하는 방법과 흥쇄유돌근을 필요시 이완시키며 효과적으로 견인하는 방법만 잘 숙지한다면 어렵지 않을 것 으로 사료된다. 뒤에 기술할 경부절제술은 가장 흔하게 시행
하는 견갑설골상부 경부절제술(supraomohyoid neck dissection)을 중심으로 저자의 일반적인 수술 순서에 기준하여 기술하였다. 자가견인기 및 보조자의 견인에 의하여 수술 공 간이 확보되면 일반적인 경우 내시경을 수술 공간 내로 삽입 하여 내시경 시야에서 수술을 진행하지만, 저자의 경우 비내 시경 시야에서 안면신경을 찾은 후 내시경을 도입하기도 한 다. 내시경을 조작하는 보조자는 술자보다 환자의 머리 측에 위치하여 내시경으로 이하선 미부와 하악측 피판을 거상하며 내시경 시야를 확보하되 내시경을 통과시켜 고정하여 내시경 자체의 움직임이 적도록 이하선 미부 쪽 피판 끝에 봉합사로 고정할 수 있는 약 $5 \mathrm{~cm}$ 길이의 관모양 또는 튜브형태로 만들 어 사용해도 된다. 안면신경의 하악분지를 찾은 후에는 이를 세심히 보존하며 하악 하연 측으로 거상 후 바로 아래의 안면 혈관(facial artery and vein)을 찾아 혈관클립(ligating clip) 과 혈관결찰기를 이용하여 결찰한다(Fig. 3, Supplementary Video 1).

\section{내시경 시야의 박리}

안면혈관 결찰 이후 안면신경 아래 안면혈관 주변의 림프 절들을 아래로 박리하며 앞쪽으로 박리를 이어간다. 반대측

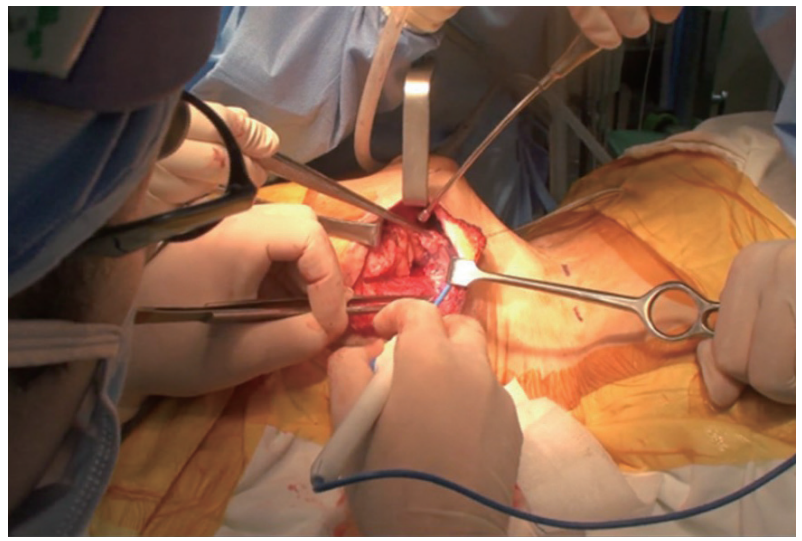

Fig. 2. Creating working space under direct view.

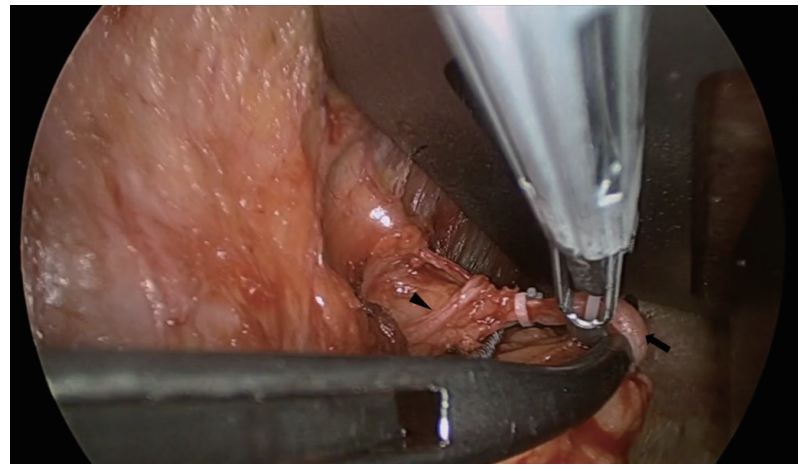

Fig. 3. Identification of marginal mandibular branch of facial nerve (arrowhead) and clipping of facial artery (arrow). 
이복근 전복의 기시부에 닿을 때까지 하악 하연의 박리를 이 어간 후 이복근 전복을 따라 아래로 박리를 진행하여 설골에 이르게 되며, 이후 이하삼각(submental triangle)의 연부조직 을 앞에서 뒤쪽으로 박리하며 악하삼각(submandibular triangle)의 박리로 이어지도록 한다(Fig. 4, Supplementary Video 1). 하악설골근(mylohyoid muscle) 주변에 이르러는 출혈과 근조직 파열에 주의를 기울이며 세심히 박리하여야 하며 하악설골근 거상 시 근조직이 쉽게 찢어질 수 있으니 예리한 겸자로 잡기보다는 끝이 뭉툭한 겸자를 이용하여 넓 게 잡도록 한다. 하악설골근 거상 후 악하선(submandibular gland) 앞측 상부의 연조직을 박리하여 악하신경절(submandibular ganglion)을 확인하고 결찰한다(Fig. 5, Supplementary Video 1). 이후 설하신경(hypoglossal nerve)과 설신경 (lingual nerve)을 주의하며 악하선관(Wharton's duct)을 결 찰 후 악하선을 후하방으로 견인하여 악하삼각으로부터 끌 어낸다. 이후 이복근 후복 윗면에서 안면동맥의 근위부를 확 인 후 클립과 혈관 결찰기를 이용하여 이중으로 결찰한다.

경부 1 구역의 박리가 끝나면 이복근의 후복을 상부로 견인 하며 후복을 따라 후방으로 박리하며 경정맥과 척수부신경 (spinal accessory nerve)의 위치를 확인 후 이하선 미부(parotid tail)와 흥쇄유돌근막의 전방 사이를 박리한다(Fig. 6,

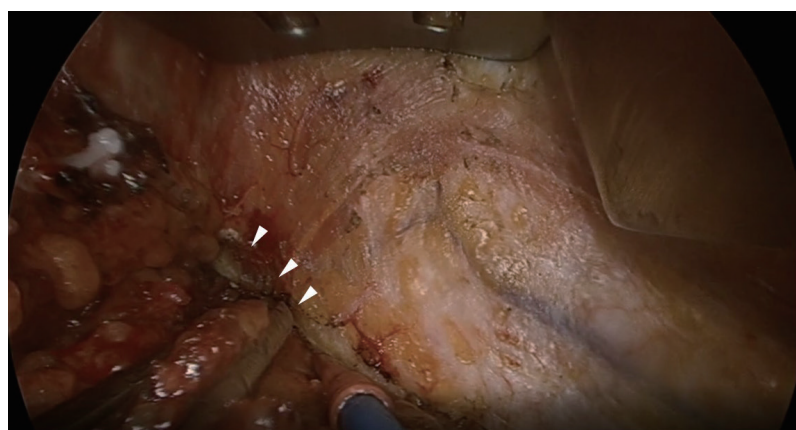

Fig. 4. Level la dissection from contralateral side of anterior belly of digastric muscle (arrowheads).

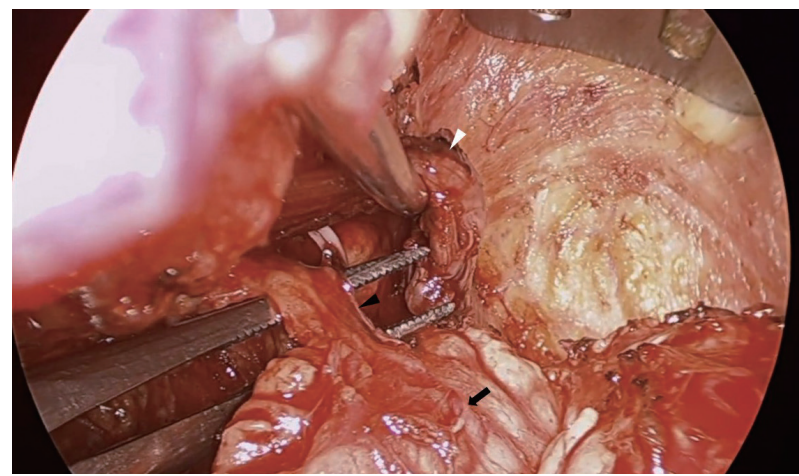

Fig. 5. Level Ib dissection. Mylohyoid muscle (white arrowhead) was elevated with Yankauer suction and submandibular ganglion (black arrowhead) was divided from submandibular gland (black arrow).
Supplementary Video 1). 이후 흥쇄유돌근막을 겸자로 잡아 서 앞쪽으로 견인하고 보조자로 하여금 직각견인기(rightangle retractor)를 이용하여 흥쇄유돌근을 후방으로 견인하 며 전기소작기를 이용하여 연조직을 전방으로 박리한다. 이 부위는 수술 공간의 입구에 해당되므로 굳이 내시경을 이용 할 필요는 없어 저자의 경우 내시경 도입 전 미리 박리를 진 행해두기도 한다. 척수부신경의 주행경로를 따라 주의 깊게 박리하여 보존한 후, 척수부신경 후상부의 $2 \mathrm{~b}$ 구역의 림프절 을 박리 후 척수부신경 전하방의 $2 \mathrm{a}$ 를 박리한다. 이 부위 박 리 시 설하신경과 ansa hypoglossi 신경의 주행에 유의하며 경정맥 전방의 림프절이 남지 않도록 내시경으로 확인하며 철저히 박리한다. 이후 단계부터는 어깨받침을 빼거나 낮은 받침으로 바꾸고 머리를 약간 동측으로 돌려서 흉쇄유돌근 의 긴장도를 줄이면 경정맥과 흥쇄유돌근 사이의 공간이 더 확보될 수 있다. 만약, 목이 가늘고 긴 환자의 경우 3구역까지 의 박리만 필요로 하다면 이와 같은 자세 변경이 필수적이지 않을 수 있으나, 그렇지 않은 경우 또는 4구역 박리 시에는 앞서 기술한 방법이 공간 확보에 많은 도움이 될 수 있다. 흥 쇄유돌근으로부터 연조직이 전방으로 박리된 후 경신경총 (cervical plexus)을 가능한 보존해가며 근막카펫(fascia carpet)보다 표재성(superficial)으로 경정맥을 향해 박리를 진행 하여 수술 시료를 경정맥 쪽에 모이게 한다. 이후 필요시 혈 관클립으로 혈관을 결찰하며 수술 시료를 경정맥에서 박리 하여 혁대근 바깥 경계까지 이르도록 한다(Figs. 7 and 8, Supplementary Video 1).

수술 시료가 모두 제거된 후 내시경을 이용하여 구역별로 철저히 출혈 부위를 확인 및 지혈 후 수술 부위를 세척하고 배액관을 유치한다. 저자의 경우 배액관은 가급적 모발선 안 에 가려지도록 모발선 측 절개선 하방에 따로 고안하거나 모 발선 내 절개선의 끝 부위를 이용하여 고정한다.

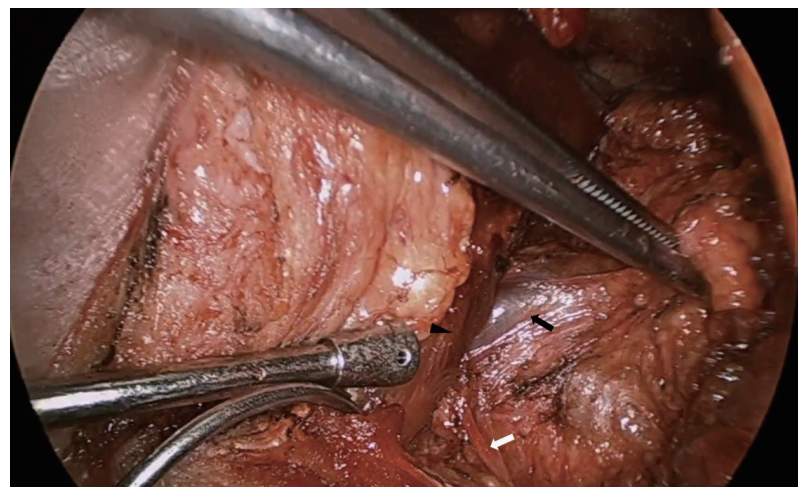

Fig. 6. Level II dissection and preservation of spinal accessory nerve (white arrow) running posteriorly from jugular vein (black arrow) and posterior belly of digastric muscle (black arrowhead). 


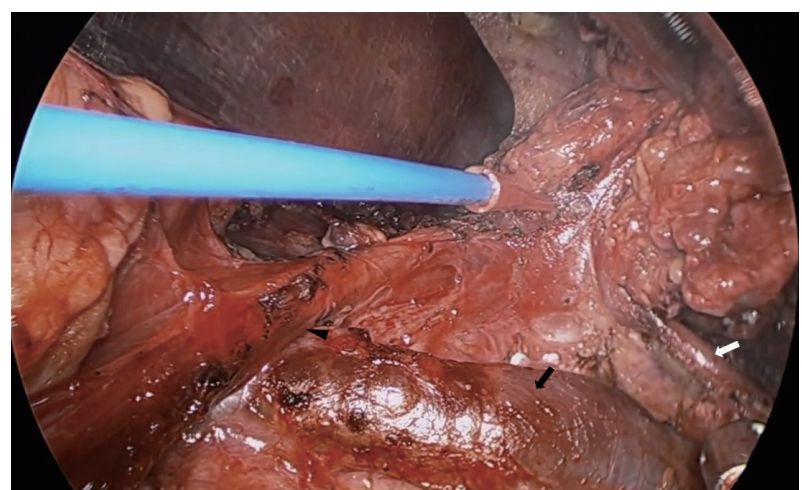

Fig. 7. Level III dissection. Note that posterior belly of digastric muscle (black arrowhead), omohyoid muscle (white arrow) and jugular vein (black arrow) were identified.

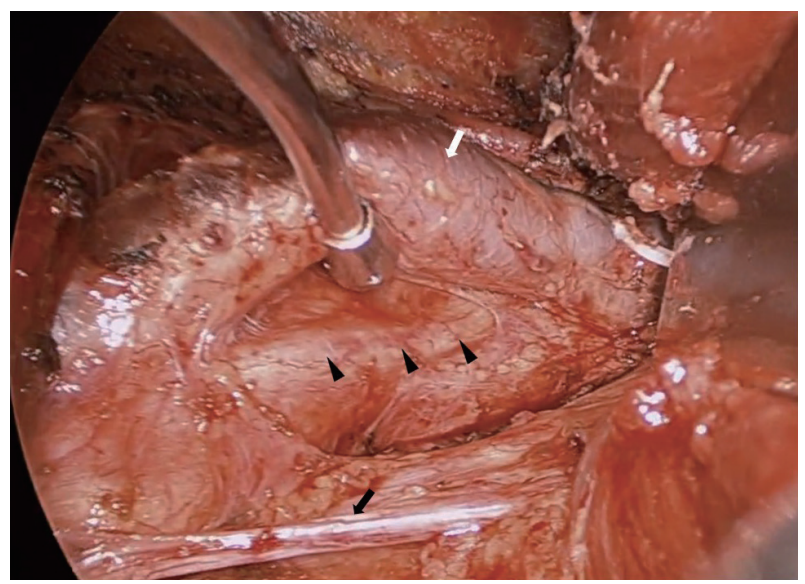

Fig. 8. Spinal accessory nerve (black arrow), jugular vein (white arrow) and contour of vagus nerve (black arrowheads) were noted during dissection of medial part of level II-III.

\section{수술 후 관리}

수술 후 관리는 일반적인 선택적 경부절제술의 경우와 다 르지 않으나 후이개 접근법의 경우 후이개 절개선의 변연이 간혹 괴사되는 경우가 있을 수 있고 특히, 모발선측과 후이개 측 절개선을 잇는 상부 곡선부가 지나치게 좁거나 예각을 이 루는 경우 피판의 괴사로 이어질 수 있어 주의를 요하며 절 개선 고안 시 이점을 반드시 고려하여 고안해야 한다. 만약 출혈이 심하여 응급 수술을 시행하게 되는 경우 후이개 절개 선을 다시 개방하여 확인 후 혈관클립과 혈관결찰기를 이용 하여 대개 충분히 지혈가능하다. 다만, 술자의 손이 직접 닿 지 않는 곳에서 대량 출혈이 있는 경우 추가 절개가 필요할 수도 있다.

\section{결 과}

후이개 접근법은 다른 접근법에 비해 경부 $1,2,3$ 구역에
대한 집도의의 직접적인 시야가 확보되며 일반적인 수술 기 구의 접근 또한 용이하여 경부절제술의 경험이 풍부한 외과 의라면 어렵지 않게 내시경을 이용한 선택적 경부절제술을 시행할 수 있다. 또한, 수술 시 대혈관 파열 및 내시경 기구를 통한 술기 외의 직접적인 수기 술기가 필요하다면 언제든 쉽 게 시행할 수 있어 내시경 수술이 처음인 술자들도 안전하게 시행할 수 있다.

\section{Supplementary Video Legend}

Video 1. Endoscopic selective neck dissection (level I, II, and III).

\section{Supplementary Materials}

The Data Supplement is available with this article at https://doi. org/10.3342/kjorl-hns.2021.00115.

\section{Acknowledgments}

None.

\section{Author Contribution}

Data curation: Joo Hyun Kim. Formal analysis: Joo Hyun Kim. Investigation: Joo Hyun Kim. Resources: Joo Hyun Kim. Software: Jae Hong Park. Supervision: Jae Hong Park. Validation: Jae Hong Park. Visualization: Jae Hong Park. Writing—original draft: Jae Hong Park. Writing — review \& editing: Jae Hong Park.

\section{ORCID}

Jae Hong Park https://orcid.org/0000-0002-5409-5581

\section{REFERENCES}

1) Vandenbrouck C, Sancho-Garnier H, Chassagne D, Saravane D, Cachin Y, Micheau C. Elective versus therapeutic radical neck dissection in epidermoid carcinoma of the oral cavity: Results of a randomized clinical trial. Cancer 1980;46(2):386-90.

2) Medina JE, Byers RM. Supraomohyoid neck dissection: Rationale, indications, and surgical technique. Head Neck 1989;11(2):111-22.

3) Suárez O. El problema de las metastasis linfáticas y alejadas del cáncer de laringe e hipofaringe. Rev Bras Otorrinolaringol 1963; 23:83-99.

4) Byers RM. Modified neck dissection. A study of 967 cases from 1970 to 1980 . Am J Surg 1985;150(4):414-21.

5) Shin YS, Chung HP, Shin HA, Lee HJ, Koh YW, Choi EC. Endoscopic axillo-breast approach for benign neck mass excision. Laryngoscope 2012;122(3):559-64.

6) Shin YS, Koh YW, Choi EC. Endoscopic removal of a cystic neck mass via an axillo-breast approach. Laryngoscope 2011;121(3):571-3.

7) Lee HS, Lee D, Koo YC, Shin HA, Koh YW, Choi EC. Endoscopic resection of upper neck masses via retroauricular approach is feasible with excellent cosmetic outcomes. J Oral Maxillofac Surg 2013;71(3):520-7.

8) Byeon HK, Holsinger FC, Koh YW, Ban MJ, Ha JG, Park JJ, et al. Endoscopic supraomohyoid neck dissection via a retroauricular or modified facelift approach: Preliminary results. Head Neck 2014; 36(3):425-30. 